\title{
Performance of lactating cows fed sugarcane silage treated with microbial additives
}

\author{
Rendimiento de vacas lactantes alimentadas con ensilaje de caña de azúcar tratadas con aditivos \\ microbianos
}

\section{Desempenho de vacas em lactação alimentadas com silagem de cana-de-açúcar tratada com aditivos microbianos}

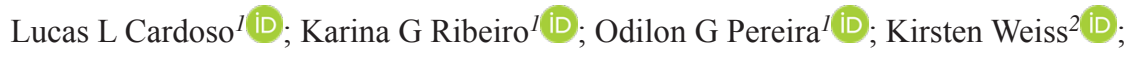
Geraldo F V Bayão $^{3(\mathbb{D})}$; Camila S Cunha ${ }^{1}$ (D); Marcos I Marcondes ${ }^{1,4 *(\mathbb{D}) .}$

\begin{abstract}
${ }^{1}$ Universidade Federal de Viçosa - Department of Animal Science, 36570-900 - Viçosa, MG - Brazil.
${ }^{2}$ Humboldt University Berlin - Faculty of Agriculture and Horticulture - Invalidenstraße 42, 10115 - Berlin - Germany.

${ }^{3}$ Department of Animal Science, Instituto Federal de Educação, Ciência e Tecnologia do Maranhão, 65095-460, Brazil.

${ }^{4}$ Department of Animal Sciences, Washington State University, WA 99164, Pullman, USA.
\end{abstract}

To cite this article:

Cardoso LL, Ribeiro KG, Pereira OG, Weiss K, Bayão GFV, Cunha CS, Marcondes MI. Performance of lactating cows fed sugarcane silage treated with microbial additives. Rev Colomb Cienc Pecu 2022; 35(1): 14-25. DOI: https://doi.org/10.17533/udea.rccp.v35n1a02

\begin{abstract}
Background: No studies have been conducted evaluating sugarcane silage associated with both Lactobacillus plantarum and Pediococcus pentosaceus for lactating dairy cows. Objective: To evaluate diets containing different roughages with and without microbial inoculants on intake, digestibility and milk yield of medium-producing cows. Methods: A total of 15 Holstein cows distributed into a randomized block design were used. Dietary treatments were: 1) a corn silage-based diet (CS), 2) a fresh sugarcane-based diet (SC), 3) a sugarcane silage ensiled without inoculant (SS), 4) sugarcane silage ensiled with Lactobacillus buchneri (SSLB), and 5) sugarcane silage ensiled with Lactobacillus plantarum and Pediococcus pentosaceus (SSLP). Results: Digestible organic matter intake (DOMI) was lower $(\mathrm{p}<0.05)$ in cows fed SSLB $\left(9.77 \mathrm{~kg}^{-1}\right.$ day $\left.^{-1}\right)$ when compared with cows fed CS (13.29 kg day $\left.{ }^{-1}\right)$ and SSLP (12.42 $\left.\mathrm{kg} \mathrm{day}^{-1}\right)$. Ensiling of sugarcane increased intake of neutral detergent fiber (NDF) compared to SC (mean of $6.00 \mathrm{~kg} \mathrm{day}^{-1}$ versus $4.97 \mathrm{~kg}$ day $^{-1} ; \mathrm{p}<0.05$ ). Dry matter digestibility was greater ( $<<0.05$ ) in $\mathrm{CS}$ $(77.80 \%)$ compared with diets based on sugarcane silage, whereas NDF digestibility was lower for treatments with sugarcane $(\mathrm{p}<0.05)$. Milk yield was similar among CS $(27.99 \mathrm{~kg})$, SC $(25.59 \mathrm{~kg})$, and silages with additives $(25.47$ and 27.07 for SSLB and SSLP, respectively). Cows fed CS produced more fat-corrected milk $(25.89 \mathrm{~kg})$ than those fed sugarcane-based diets $(p<0.05)$. Conclusions: Fresh sugarcane or sugarcane silage with additives can be used as a roughage source for dairy cows producing up to $23.43 \mathrm{~kg} \mathrm{~d}^{-1}$ fat-corrected milk, considering the total diet is properly balanced.
\end{abstract}

Received: May 7, 2020; accepted: May 26, 2021

*Corresponding author. RWA 99163 - Pullman - USA. E-mail: marcos.marcondes@wsu.edu

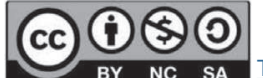
(c) 2022 Universidad de Antioquia. Publicado por Universidad de Antioquia, Colombia. 
Keywords: cows; digestibility; dry matter intake; Holstein; Lactobacillus buchneri; Lactobacillus plantarum; microbial additives; microbial inoculants; milk yield; Pediococcus pentosaceus; roughage.

\section{Resumen}

Antecedentes: No existen estudios que evalúen la adición de Lactobacillus plantarum y Pediococcus pentosaceus en el ensilaje de caña de azúcar para vacas lactantes. Objetivo: Evaluar dietas con diferentes forrajes y ensilajes con y sin inoculantes microbianos sobre el consumo, digestibilidad y producción lactea de vacas de mediana producción. Metodología: Quince vacas Holstein se distribuyeron en un diseño de bloques al azar. Los tratamientos fueron: 1) dieta con ensilaje de maíz (CS), 2) dieta con caña de azúcar fresca (SC), 3) dieta con ensilaje de caña sin inoculantes (SS), 4) dieta con ensilaje de caña de azúcar ensilada con Lactobacillus buchneri (SSLB), y 5) dieta con ensilaje de caña de azúcar ensilada con Lactobacillus plantarum y Pediococcus pentosaceus (SSLP). Resultados: El consumo de materia orgánica digestible fue menor $(\mathrm{p}<0,05)$ en la dieta $\operatorname{SSLB}\left(9,77 \mathrm{~kg} \mathrm{day}^{-1}\right)$ en comparación con CS (13,29 $\left.\mathrm{kg} \mathrm{dia}^{-1}\right)$ y $\operatorname{SSLP}\left(12,42 \mathrm{~kg} \mathrm{dia}^{-1}\right)$. El ensilaje de caña de azúcar promovió un mayor consumo de fibra detergente neutra (NDF) en comparación con SC (promedio de 6,00 $\mathrm{kg} \mathrm{dia}^{-1}$ versus 4,97 kg dia-1; $\mathrm{p}<0,05)$. La digestibilidad de la materia seca fue mayor $(\mathrm{p}<0,05)$ para la dieta CS $(77,80 \%)$ en comparación con las dietas con ensilaje de caña de azúcar, mientras que la digestibilidad de la NDF fue menor para las dietas a base de caña de azúcar (p<0,05). La producción de leche fue similar entre CS $(27,99 \mathrm{~kg})$, SC $(25,59 \mathrm{~kg})$ y ensilajes con aditivos $(25,47$ y 27,07 para SSLB y SSLP, respectivamente). Las vacas alimentadas con ensilaje de maíz produjeron más leche corregida por grasa $(25,89 \mathrm{~kg})$ que las alimentadas con dietas a base de caña de azúcar $(\mathrm{p}<0,05)$. Conclusión: La caña de azúcar fresca o ensilada con aditivos se puede utilizar como fuente de forraje para vacas que producen hasta $23,43 \mathrm{~kg} \mathrm{~d}^{-1}$ leche corregida por grasa, siempre que la dieta total esté equilibrada adecuadamente.

Palabras clave: aditivos microbianos; consumo de materia seca; digestibilidad; forraje; Holandés; inoculantes microbianos; Lactobacillus buchneri; Lactobacillus plantarum; Pediococcus pentosaceus; producción de leche; vaca.

\section{Resumo}

Antecedentes: Há carência de estudos avaliando a adição de Lactobacillus plantarum e Pediococcus pentosaceus na silagem de cana-de-açúcar para vacas em lactação. Objetivo: Avaliar dietas contendo diferentes forragens e silagens com e sem inoculantes microbianos sobre o consumo, digestibilidade e produção de leite de vacas de média produção de leite. Métodos: Quinze vacas Holandesas foram distribuídas em um delineamento em blocos casualizados. Os tratamentos foram: 1) dieta com silagem de milho (CS), 2) dieta com cana-de-açúcar fresca (SC), 3) dieta com silagem de cana ensilada sem inoculantes (SS), 4) dieta com silagem de cana-de-açúcar ensilada com Lactobacillus buchneri (SSLB), ou 5) dieta com silagem de canade-açúcar ensilada com Lactobacillus plantarum, and Pediococcus pentosaceus (SSLP). Resultados: O consumo de matéria orgânica digestível foi menor $(\mathrm{p}<0,05)$ na dieta SSLB $\left(9,77 \mathrm{~kg} \mathrm{day}^{-1}\right)$ comparada com CS $\left(13,29 \mathrm{~kg}\right.$ dia $\left.{ }^{-1}\right)$ e SSLP $(12,42 \mathrm{~kg}$ $\left.\mathrm{dia}^{-1}\right)$. A ensilagem da cana-de-açúcar promoveu maior consumo de fibra em detergente neutro (FDN) em comparação com $\mathrm{SC}$ (média de $6,00 \mathrm{~kg} \mathrm{dia}^{-1}$ versus $4.97 \mathrm{~kg} \mathrm{dia}^{-1} ; \mathrm{p}<0.05$ ). A digestibilidade da matéria seca foi maior $(\mathrm{p}<0,05)$ para a dieta CS $(77,80 \%)$ comparada com as dietas com silagem de cana-de-açúcar, enquanto que a digestibilidade da FDN foi menor para as dietas baseadas em cana-de-açúcar ( $\mathrm{p}<0,05)$. A produção de leite foi similar entre CS $(27,99 \mathrm{~kg}), \mathrm{SC}(25,59 \mathrm{~kg})$ e silagens com aditivos (25,47 e 27,07 para SSLB e SSLP, respectivamente). Vacas alimentadas com silagem de milho produziram mais leite corrigido para gordura $(25,89 \mathrm{~kg})$ que aquelas alimentadas com dietas baseadas em cana-de-açúcar ( $<<0,05)$. Conclusão: A cana-de-açúcar fresca ou ensilada com aditivos pode ser utilizada como fonte volumosa para vacas produzindo até $23,43 \mathrm{~kg} \mathrm{~d}^{-1}$ leite corrigido para gordura, desde que a dieta total esteja apropriadamente balanceada.

Palavras-chave: aditivos microbianos; consumo de matéria seca; digestibilidade; forragem; Holandês; inoculantes microbianos; Lactobacillus buchneri; Lactobacillus plantarum; Pediococcus pentosaceus; produção de leite; vaca. 


\section{Introduction}

Ensiling sugarcane is an alternative for daily chop, but its fermentation can lead to high concentrations of ethanol and large dry matter losses (Ávila et al. 2010, Pedroso et al. 2011). Sugarcane silages are also prone to spoil rapidly when exposed to air because of high epiphytic populations of yeasts (Ávila et al. 2012). Microbial additives such as Lactobacillus buchneri can aid in the fermentation process by improving dry matter (DM) recovery, aerobic stability and decreasing production of ethanol (Schmidt et al., 2014). Bacterial inoculants based on homofermentative strains containing Lactobacillus plantarum and Pediococcus pentosaceus have been used to improve chemical features of silages, such as reducing $\mathrm{pH}$, and increasing lactic acid content (Zielińska et al., 2015). The use of different strains as inoculant improves the chance of success because the selected strains will act together, complementarily, resulting in a better pattern of fermentation and anaerobic stability than when only one strain is used. Queiroz et al. (2008) and Andrade et al. (2016) have reported similar milk yield (MY) and energy corrected milk (ECM) when feeding sugarcane silage with Lactobacillus buchneri, corn silage or fresh sugarcane for dairy cows, as long as the diets are properly balanced. Santos et al. (2017), on the other hand, did not find beneficial effects when studying sugarcane silage with Lactobacillus buchneri. These inconsistences highlight the need for further research on this topic. To the best of our knowledge, no studies have been conducted evaluating sugarcane silage of Lactobacillus plantarum and Pediococcus pentosaceus added together for lactating dairy cows. Additionally, Queiroz et al. (2008) and Andrade et al. (2016) are the only studies using medium-producing dairy cows $(>20 \mathrm{~L} / \mathrm{d})$.

We hypothesized that medium-producing cows fed sugarcane silage-based diets treated with microbial additives would have a similar intake, digestibility, and MY to that of cows fed corn silage-based diet or fresh sugarcane-based diet. Our second hypothesis was that cows fed sugarcane silage-based diets with microbial additives would have greater performance when compared with cows fed a sugarcane silage-based diet without additives. Therefore, the objective of the present study was to evaluate diets containing different roughages with and without microbial inoculants on intake, digestibility, and MY of medium producing cows.

\section{Materials and Methods}

\section{Ethical considerations}

The experiment was conducted at Viçosa, Minas Gerais, Brazil (20 45' 14" S longitude; $42^{\circ} 51^{\prime} 54^{\prime \prime}$ W latitude; altitude $\left.651 \mathrm{~m}\right)$. All procedures were conducted in accordance with the guidelines set out by the Brazilian College of Animal Experimentation in the Code of Practice for the Care and Use of Animals for Experimental Purposes, and were reviewed and approved by the Ethics Committee on Use of Animal for Research of Universidade Federal de Viçosa (protocol number 27/2013). The number of replicates required per treatment was determined by the Ethics Committee on Animal Production Use at the Universidade Federal de Viçosa through power analysis (Morris, 1999) for the primary response variables, including dry matter intake (DMI), digestibility and MY.

\section{Animals and experiments}

A total of 15 multiparous Holstein cows, producing $29.0 \pm 5.0 \mathrm{~kg} \mathrm{~d}^{-1}$ of milk on average, at $112.4 \pm 11.8$ days in milk and averaging $578.0 \pm 8.3 \mathrm{~kg}$ body weight $(\mathrm{BW})$ were used and distributed in a randomized block design, with three replications and five blocks using MY as a blocking factor.

The animals underwent an adaptation period to the diet and management during the 15 days prior to the experiment. The experimental period lasted 127 days with four periods of 28 days each for data collection and sampling, without diet changes among animals. Total mixed rations varied in the following proportions (DM basis) of roughage sources: corn silage-based diet $(60 \%$, CS, hybrid Biomatrix 7049 herculex, 
Agroceres company, Patos de Minas, Minas Gerais, Brazil), fresh sugarcane $(40 \%, \mathrm{SC}$, hybrid RB867515, developed by Universidade Federal de Viçosa, Viçosa, Minas Gerais, Brazil), diet based on sugarcane silage $(40 \%$, SS, hybrid RB867515) ensiled without inoculant, diet based on sugarcane silage (hybrid RB867515) ensiled with $5 \times 10^{4} \mathrm{cfu} \mathrm{g}^{-1}$ Lactobacillus buchneri (SiloMax Cana, Matsuda, São Paulo, Brazil) $(40 \%, \mathrm{SSLB})$, and ensiled with $5 \times 10^{4} \mathrm{cfu} / \mathrm{g}$ Lactobacillus plantarum and $5 \times 10^{4} \mathrm{cfu} \mathrm{g}^{-1}$ Pediococcus pentosaceus (SiloMax Centurium , Matsuda, São Paulo, Brazil) (40\%, SSLP). The inoculant dosages were used at $2 \mathrm{~g}$ of inoculant per ton of fresh chopped sugarcane, which was applied using a 20 L backpack sprayer. Corn was harvested at about 110 days of maturity, 280 g. $\mathrm{kg}^{-1} \mathrm{DM}$, ensiled with $3-5 \mathrm{~cm}$ in length and packed with $520 \mathrm{~kg} \mathrm{~m}^{-3}$ density. Fresh sugarcane was harvested daily with nine months of growth, averaged 230 g. $\mathrm{kg}^{-1} \mathrm{DM}$ and was chopped at 3-5 cm length. The sugarcane used for silage was harvested at 12 months of maturity, with 270 g. $\mathrm{kg}^{-1}$ of DM, chopped at 3-5 cm length and packed with $550 \mathrm{~kg} \mathrm{~m}^{-3}$ density. Sugarcane silages with inoculants were treated during the ensiling process. Ensiled forages were stored in separate bunker silos for three months prior to the experiment.

Diets were formulated to be isonitrogenous (17 $\left.\mathrm{g} \mathrm{CP} \mathrm{kg}^{-1} \mathrm{DM}\right)$, and isocaloric $(1.63 \mathrm{Mcal}$ NEL $\left.\mathrm{kg}^{-1} \mathrm{DM}\right)$ to meet the requirements of $650-\mathrm{kg}$ cows with an average MY of $27 \mathrm{~kg}$ milk per day according to NRC (2001). The CS had a roughage to concentrate ratio of $60: 40$, and sugarcane-based diets had a roughage to concentrate ratio of 40:60 to provide the same energy density (Table 1). These adaptations were needed to achieve similar contents of CP and energy among diets. However, sugarcane used for silages presented greater concentrations of CP than the tabulated value used when diets were balanced. Thus, the formulated diets were isonitrogenous but the diet offered to cows were not. Cows were fed ad libitum twice daily (07h00 and 16h00) after the morning and afternoon milking, allowing a maximum of $10 \%$ orts. At the beginning and end of the experimental period, all animals were weighed after a 12-h fasting period.

Table 1. Proportion of forage and concentrate, and ingredients in the concentrate of the experimental diets (g/kg of DM).

\begin{tabular}{lccccc}
\hline \multirow{2}{*}{ Ingredients } & \multicolumn{5}{c}{ Treatments } \\
\cline { 2 - 5 } & CS & SC & SS & SSLB & SSLP \\
\hline Forage & 600 & 400 & 400 & 400 & 400 \\
Soybean meal & 240 & 219 & 219 & 219 & 219 \\
Ground corn & 107 & 306 & 308 & 308 & 308 \\
Urea & 0.24 & 10.98 & 9.90 & 9.90 & 9.90 \\
Ammonium sulfate & 6.64 & 8.04 & 8.04 & 8.04 & 8.04 \\
Sodium chloride & 5.16 & 5.88 & 5.88 & 5.88 & 5.88 \\
Limestone & 8.04 & 9.12 & 9.18 & 9.18 & 9.18 \\
Dicalcium phosphate & 7.80 & 11.10 & 11.10 & 11.10 & 11.10 \\
Magnesium oxide & 2.28 & 1.62 & 1.62 & 1.62 & 1.62 \\
Sodium bicarbonate & 5.72 & 4.02 & 4.02 & 4.02 & 4.02 \\
Mineral mix & 17.4 & 22.8 & 22.8 & 22.8 & 22.8 \\
\hline
\end{tabular}

CS: corn silage; SC: fresh sugarcane; SS: sugarcane silage without additives; SSLB: sugarcane silage with 5 x $10^{4}$ cfu of Lactobacillus buchneri; SSLP: sugarcane silage with $5 \times 10^{4}$ cfu Lactobacillus plantarum and $5 \times 10^{4}$ cfu Pediococcus pentosaceus. Mineral mix: $4 \mathrm{~g} / \mathrm{kg}$ of cobalt sulfate, $6 \mathrm{~g} / \mathrm{kg}$ of sodium selenite, $15 \mathrm{~g} / \mathrm{kg}$ of potassium iodate, $433 \mathrm{~g} / \mathrm{kg}$ of copper sulfate, and 542 $\mathrm{g} / \mathrm{kg}$ of zinc sulfate. 
Forage and orts were collected from day seven to sixteen of each experimental period. Ingredients of the concentrate were sampled at the feed mills once per period. From day eight to fifteen, fecal samples were collected. Composite samples were made per period for the feeds supplied, and one sample of orts was made per animal per period. These samples were partially dried at $55{ }^{\circ} \mathrm{C}$ for $72 \mathrm{~h}$ in a forced ventilation oven and ground in a Willey mill (Thomas Scientific, Swedesboro, NJ, USA) with a $1-\mathrm{mm}$ screen for determination of nutrients' composition (Table 2) as follows: DM (Method 934.01; AOAC, 1990), organic matter (OM) (method 942.05; AOAC, 1990), CP (method 920.87; AOAC, 1990), and ether extract (EE) (Ankom ${ }^{\circledR}$ method; AOCS, 2004). For the NDF analysis, samples were treated with heat-stable alpha-amylase without the use of sodium sulphite and were corrected for residual ash and protein (Licitra et al., 1996). The nonfiber carbohydrates (NFC) were calculated as proposed by Detmann \& Valadares Filho (2010) considering corrections due to urea presence in the diet. Apparent nutrient digestibility was estimated using indigestible neutral detergent insoluble fiber (iNDF) as a marker (Detmann et al., 2012). The TDN was determined according to Weiss et al. (1992).

Milk was sampled according to recommendations of Broderick \& Clayton (1997), and $40 \mathrm{~mL}$ of milk was stored in tubes containing Bronopol ${ }^{\circledR}$ and later analyzed using a MilkoScan ${ }^{\circledR}$ FT 120 analyser (Foss Electric, Hillerod, Denmark). MY was corrected for 4\% fat (Gaines, 1928).

\section{Blood sampling}

Blood was collected four hours after the morning feeding via jugular venipuncture using tubes containing EDTA on the $28^{\text {th }}$ day of each period. Samples were immediately centrifuged at 2,700 $\times g$ for 20 minutes for plasma separation, and were stored at $-18^{\circ} \mathrm{C}$ for analysis of plasma urea-nitrogen (PUN; Talke \& Schubert, 1965), which was obtained by multiplying the urea content by 0.466 .

\section{Urine sampling}

On the same day of blood collection, $60 \mathrm{~mL}$ of urine was sampled, from which $10 \mathrm{~mL}$ was immediately diluted into $40 \mathrm{~mL}$ of a $0.036 \mathrm{~N}$ sulphuric acid solution for analysis of purine derivatives. The analyses of allantoin were performed as described by Chen \& Gomes (1992). Uric acid was quantified according to George et al. (2006). Creatinine was evaluated by the colorimetric method using commercial kits (555-A Sigma Chemical Co., St. Louis, MO, USA).

Microbial efficiency (MICEF) was determined by dividing the microbial protein synthesis (estimated as described by Chen \& Gomes, 1992) by total digestible nutrients' (TDN) intake.

\section{Statistical analysis}

All variables were analyzed using the procedure MIXED of SAS, version 9.2 (SAS Institute Inc., Cary, NC, USA; 2008). MY and intake were analyzed weekly (240 sampling units) according to the following model:

$$
\mathrm{Y}_{\mathrm{ijke}}=\mu+\mathrm{D}_{\mathrm{i}}+\beta_{\mathrm{j}}+\delta_{\mathrm{ijk}}+\mathrm{Pe}_{\mathrm{e}}+(\mathrm{D} \times \mathrm{P})_{\mathrm{ie}}+\varepsilon_{\mathrm{ijke}},
$$
where:

$\mu=$ general mean;

$\mathrm{D}_{\mathrm{i}}=$ fixed effect of the $i$ treatment;

$\beta_{\mathrm{j}}=$ random effect of the $j$ block;

$\delta_{\mathrm{ijk}}=$ random error with mean 0 and variance $\sigma^{2} \delta$; the variance among animals in the treatment is equal to the covariance among repeated measures of the animals;

$\mathrm{Pe}_{\mathrm{e}}=$ fixed effect of period;

$(\mathrm{D} \times \mathrm{P})_{\mathrm{ie}}=$ fixed effect of the interaction between $i$ treatment and $e$ period, and $\varepsilon_{\mathrm{ijke}}=$ random error with mean 0 and variance $\tau^{2}$, the variance among measures between animals. 
Table 2. Chemical composition of the forage concentrate and total mixed rations (TMR) values expressed in $g$ $\mathrm{kg}^{-1}$ of DM (average of 16 samples taken weekly).

\begin{tabular}{|c|c|c|c|c|c|}
\hline \multirow{2}{*}{ Item } & \multicolumn{5}{|c|}{ Treatments } \\
\hline & CS & SC & SS & SSLB & SSLP \\
\hline & \multicolumn{5}{|c|}{ Forage } \\
\hline Dry matter & 220.1 & 232.2 & 213.9 & 206.4 & 211 \\
\hline Organic matter & 957.2 & 954.8 & 929.9 & 926.2 & 938.5 \\
\hline Crude protein & 88.8 & 45.5 & 41.8 & 49.5 & 37.5 \\
\hline Ether extract & 40.1 & 25.3 & 17.4 & 24.6 & 22.3 \\
\hline Neutral detergent fiber(ap $)^{l}$ & 533.8 & 578.2 & 714 & 707.1 & 665.7 \\
\hline Non-fiber carbohydrates & 294.5 & 305.7 & 156.7 & 144.9 & 213 \\
\hline \multirow[t]{2}{*}{ Indigestible neutral detergent fiber } & 105 & 230.1 & 248.5 & 265.1 & 226.5 \\
\hline & \multicolumn{5}{|c|}{ Concentrate } \\
\hline Dry matter & 777.5 & 775 & 815.6 & 815.6 & 815.6 \\
\hline Organic matter & 911.8 & 901.8 & 908.3 & 908.3 & 908.3 \\
\hline Crude protein & 211.5 & 226.5 & 281.6 & 281.6 & 281.6 \\
\hline Ether extract & 32.2 & 18.3 & 32 & 32 & 32 \\
\hline Neutral detergent fiber(ap) & 105.8 & 112 & 112.5 & 112.5 & 112.5 \\
\hline Non-fiber carbohydrates & 606.4 & 580.1 & 517.3 & 517.3 & 517.3 \\
\hline \multirow[t]{2}{*}{ Indigestible neutral detergent fiber } & 7.6 & 10.1 & 6.6 & 6.6 & 6.6 \\
\hline & \multicolumn{5}{|c|}{$T M R^{2}$} \\
\hline Dry matter & 444.2 & 561 & 572.8 & 569.9 & 571.7 \\
\hline Organic matter & 939.1 & 923 & 918.4 & 917 & 921.9 \\
\hline Crude protein & 137.9 & 154.1 & 187 & 190.1 & 185.3 \\
\hline Ether extract & 36.9 & 21.1 & 25.9 & 28.8 & 27.9 \\
\hline Neutral detergent fiber(ap) & 362.6 & 298.5 & 353.1 & 350.3 & 333.7 \\
\hline Non-fiber carbohydrates & 419.3 & 470.4 & 373 & 368.3 & 395.6 \\
\hline Indigestible neutral detergent fiber & 66 & 98.1 & 103.2 & 109.8 & 94.4 \\
\hline
\end{tabular}

CS: corn silage-based diet; SC: fresh sugarcane; SS: sugarcane silage-based diet without additives; SSLB: sugarcane silage-based diet with $5 \times 10^{4} \mathrm{cfu}$ of Lactobacillus buchneri; SSLP: sugarcane silage-based diet with $5 \times 10^{4} \mathrm{cfu}$ Lactobacillus plantarum and $5 \times 10^{4} \mathrm{cfu}$ Pediococcus pentosaceus.

${ }^{I}$ Neutral detergent fiber corrected for ash and protein;

${ }^{2}$ Values calculated by the ratio 60:40 for CS, and 40:60 for SC, SS, SSLB, SSLP.

Means were compared using the least square mean linear hypothesis, and differences were considered significant at $p \leq 0.05$.

\section{Results}

Digestible organic matter intake (DOMI) was lower in cows fed SSLB when compared with cows fed CS and SSLP $(\mathrm{p}<0.05)$ (Table 3). The CS had a greater DOMI $(\mathrm{p}<0.05)$ compared with SC, SS and SSLB.
The CP intake was greater $(\mathrm{p}<0.05)$ in sugarcane silage-based diets when compared with diets with CS or SC. In addition, NDF intake was reduced when cows were fed SC compared with cows fed CS and all sugarcane silage-based diets. However, cows on SSLB ate less NDF than those fed CS $(p<0.05)$, and consumed less NFC than those fed CS or SC $(p<0.05)$. Cows fed the SC diet also consumed more NFC than those fed SS $(p<0.05)$. NEL intake was greater for CS. Intake of iNDF ( $\mathrm{kg} \mathrm{day}^{-1}$ and $\left.\mathrm{g} \mathrm{kg}^{-1} \mathrm{BW}\right)$ 
was greater for SS and SSLB compared to CS, $\mathrm{SC}$ and SSLP.

The apparent digestibility of DM $(p<0.05)$, $\mathrm{OM}(\mathrm{p}<0.05), \operatorname{NDF}(\mathrm{p}<0.05)$, and NFC $(\mathrm{p}<0.05)$ were greater in cows fed CS when compared with cows fed all sugarcane silage-based diets, with or without additives, but they did not differ from cows fed SC, except for NDF digestibility. The CP digestibility was not affected by diet.

Cows fed SS produced less milk than those fed CS and SSLP (Table 4). Milk fat (MF) in percentage and $\mathrm{kg}$ were not different among treatments $(p<0.05)$. Cows fed SSLP had lower milk protein (MP) than that of other diets $(p<0.05)$. However, no differences were observed in MP expressed in $\mathrm{kg}$ and in milk nitrogen $(\mathrm{MN} ; \mathrm{kg})$. The efficiency of nitrogen usage was greater for CS and SC than for the sugarcane silages. The MICEF did not differ among treatments. Cows fed SS had higher PUN when compared with other diets $(p<0.05)$. No treatment by period interactions were observed.

\section{Discussion}

Corn silage is often the standard forage, which could be observed in the present study as cows fed CS had greater DM and OM digestibilities when compared with cows fed diets based on sugarcane silage.

Table 3. Nutrient intake and apparent digestibility in cows fed corn silage-based diet or sugarcane-based diets under different conservation methods.

\begin{tabular}{|c|c|c|c|c|c|c|c|c|c|}
\hline \multirow[t]{2}{*}{ Item } & \multicolumn{5}{|c|}{ Diets } & \multicolumn{3}{|c|}{$P$-value ${ }^{I}$} & \multirow[t]{2}{*}{ SEM } \\
\hline & CS & SC & SS & SSLB & SSLP & D & $\mathbf{P}$ & D X P & \\
\hline \multicolumn{10}{|c|}{ Intake $\left(\mathrm{kg} \mathrm{day}^{-1}\right)$} \\
\hline DM & 17.89 & 16.32 & 17.34 & 16.86 & 17.91 & 0.850 & 0.003 & 0.770 & 0.31 \\
\hline $\mathrm{OM}$ & 16.83 & 15.09 & 15.91 & 15.44 & 16.50 & 0.790 & 0.012 & 0.679 & 0.29 \\
\hline DOMI & $13.29^{\mathrm{a}}$ & $10.47^{\mathrm{bc}}$ & $10.84^{b c}$ & $9.77^{\mathrm{c}}$ & $12.42^{\mathrm{ab}}$ & 0.021 & 0.019 & 0.215 & 0.31 \\
\hline $\mathrm{CP}$ & $2.48^{\mathrm{b}}$ & $2.45^{\mathrm{b}}$ & $3.23^{\mathrm{a}}$ & $3.22^{\mathrm{a}}$ & $3.31^{\mathrm{a}}$ & 0.001 & 0.015 & 0.574 & 0.07 \\
\hline NDF & $6.44^{\mathrm{a}}$ & $4.97^{\mathrm{c}}$ & $6.13^{\mathrm{ab}}$ & $5.86^{\mathrm{b}}$ & $6.02^{\mathrm{ab}}$ & 0.001 & 0.087 & 0.607 & 0.12 \\
\hline NFC & $7.25^{\mathrm{ab}}$ & $7.30^{\mathrm{a}}$ & $6.08^{\mathrm{bc}}$ & $5.87^{\mathrm{c}}$ & $6.66^{\mathrm{ab}}$ & 0.001 & 0.763 & 0.866 & 0.16 \\
\hline NEL & $1.69^{\mathrm{a}}$ & $1.30^{\mathrm{c}}$ & $1.35^{\mathrm{c}}$ & $1.23^{\mathrm{c}}$ & $1.42^{\mathrm{b}}$ & 0.034 & 0.020 & 0.578 & 0.30 \\
\hline iNDF & $0.91^{\mathrm{c}}$ & $1.47^{\mathrm{c}}$ & $1.61^{\mathrm{a}}$ & $1.63^{\mathrm{a}}$ & $1.55^{\mathrm{b}}$ & 0.015 & 0.020 & 0.103 & 0.13 \\
\hline \multicolumn{10}{|c|}{ Intake $\left(\mathrm{g} \mathrm{kg}^{-1} \mathrm{BW}\right)$} \\
\hline $\mathrm{DM}$ & 28.7 & 26.3 & 30.3 & 29.2 & 32.4 & 0.400 & 0.010 & 0.460 & 0.06 \\
\hline NDF & $10.3^{\mathrm{a}}$ & $8.0^{\mathrm{b}}$ & $10.7^{\mathrm{a}}$ & $10.1^{\mathrm{a}}$ & $10.9^{\mathrm{a}}$ & 0.001 & 0.226 & 0.672 & 0.02 \\
\hline iNDF & $0.146^{\mathrm{c}}$ & $0.236^{\mathrm{c}}$ & $0.281^{\mathrm{a}}$ & $0.281^{\mathrm{a}}$ & $0.280^{\mathrm{b}}$ & 0.004 & 0.011 & 0.103 & 0.02 \\
\hline \multicolumn{10}{|c|}{ Digestibility (\%) } \\
\hline $\mathrm{DM}$ & $77.8^{\mathrm{a}}$ & $70.2^{\mathrm{ab}}$ & $67.1^{\mathrm{b}}$ & $62.0^{\mathrm{b}}$ & $66.2^{\mathrm{b}}$ & 0.017 & 0.029 & 0.738 & 0.02 \\
\hline $\mathrm{OM}$ & $79.0^{\mathrm{a}}$ & $71.1^{\mathrm{ab}}$ & $68.2^{\mathrm{b}}$ & $62.9^{\mathrm{b}}$ & $67.5^{\mathrm{b}}$ & 0.011 & 0.023 & 0.709 & 0.02 \\
\hline $\mathrm{CP}$ & 88.0 & 83.2 & 88.7 & 87.0 & 87.6 & 0.459 & 0.005 & 0.127 & 0.01 \\
\hline NDF & $68.8^{\mathrm{a}}$ & $53.8^{\mathrm{b}}$ & $50.7^{\mathrm{b}}$ & $42.5^{\mathrm{b}}$ & $47.0^{\mathrm{b}}$ & 0.005 & 0.012 & 0.867 & 0.02 \\
\hline NFC & $84.2^{\mathrm{a}}$ & $78.8^{\mathrm{ab}}$ & $74.8^{\mathrm{bc}}$ & $70.2^{\mathrm{c}}$ & $75.4^{\mathrm{bc}}$ & 0.040 & 0.226 & 0.234 & 0.01 \\
\hline
\end{tabular}

DM: dry matter; OM: organic matter; DOMI: digestible organic matter ingested; CP: crude protein; NDF: neutral detergent fiber; NFC: non-fibrous carbohydrates; NEL: net energy for lactation; iNDF: indigestible neutral detergent fiber.

CS: corn silage-based diet; SC: fresh sugarcane; SS: sugarcane silage-based diet without additives; SSLB: sugarcane silage-based diet with $5 \times 10^{4} \mathrm{cfu}$ of Lactobacillus buchneri; SSLP: sugarcane silage-based diet with $5 \times 10^{4}$ cfu Lactobacillus plantarum and $5 \times 10^{4}$ cfu Pediococcus pentosaceus.

${ }^{l}$ Described levels of probability (p-value) for diets (D), period (P), and the interaction of diets and periods (DxP). 
However, the study of sugarcane silage for lactating cows is of high relevance in tropical areas since sugarcane has high productivity per area and its preservation as silage avoids the daily chop activity and might improve nutrient digestibility. In general, sugarcane silage-based diets were able to maintain cows' performance similar to SC level since greater amounts of $\mathrm{CP}$ are provided. This is supported by the absence of diet effect on DM and OM intake which might be due to the roughage:concentrate ratios used in this study. Diets containing corn silage presented a 60:40 roughage:concentrate ratio versus a 40:60 ratio for diets containing fresh and ensiled sugarcane, ensuring an adequate balance of dietary energy.
The adequate energy balance promoted a similar performance among the cows, except for SS. Sugarcane ensiled with inoculants were able to sustain MY similar to CS and SC if greater amounts of concentrate and $\mathrm{CP}$ are supplied. Interestingly, past studies have also shown that a greater level of concentrate in sugarcane diets yields similar MY when compared with corn silage-based diets (Costa et al., 2009; Rangel et al., 2010). The DOMI was significantly lower for SSLB when compared with CS and SSLP, and perhaps the presence of this additive induced an increased production of acetic acid and, consequently, lower yeast production, but it has not been translated in lower MY. There were no differences between the two inoculants for MY,

Table 4. Performance, milk composition, blood and milk urea nitrogen, and microbial protein synthesis of cows fed corn silage-based diet or sugarcane in different conservation methods.

\begin{tabular}{|c|c|c|c|c|c|c|c|c|c|}
\hline \multirow[t]{2}{*}{ Item } & \multicolumn{5}{|c|}{ Diets } & \multicolumn{3}{|c|}{$P$-value ${ }^{I}$} & \multirow[t]{2}{*}{ SEM } \\
\hline & CS & SC & SS & SSLB & SSLP & D & $\mathbf{P}$ & D X P & \\
\hline MY (kg) & $27.99^{\mathrm{a}}$ & $25.59^{\mathrm{ab}}$ & $23.40^{\mathrm{b}}$ & $25.47^{\mathrm{ab}}$ & $27.07^{\mathrm{a}}$ & 0.008 & 0.763 & 0.998 & 0.56 \\
\hline $\mathrm{ECM}(\mathrm{kg})$ & $25.89^{\mathrm{a}}$ & $22.29^{\mathrm{b}}$ & $21.56^{\mathrm{b}}$ & $23.43^{\mathrm{b}}$ & $23.28^{b}$ & 0.002 & 0.414 & 0.706 & 0.48 \\
\hline MP (\%) & $2.99^{a}$ & $3.09^{\mathrm{a}}$ & $2.97^{\mathrm{a}}$ & $3.05^{\mathrm{a}}$ & $2.63^{\mathrm{b}}$ & 0.030 & 0.102 & 0.494 & 0.03 \\
\hline MP (kg) & 0.76 & 0.79 & 0.69 & 0.77 & 0.72 & 0.797 & 0.761 & 0.364 & 0.08 \\
\hline MN (kg) & 0.12 & 0.12 & 0.11 & 0.12 & 0.11 & 0.797 & 0.761 & 0.364 & 0.01 \\
\hline EN (\%) & $0.30^{\mathrm{a}}$ & $0.32^{\mathrm{a}}$ & $0.21^{\mathrm{b}}$ & $0.24^{b}$ & $0.21^{\mathrm{b}}$ & $<0.001$ & 0.250 & 0.100 & 0.01 \\
\hline MF (\%) & 3.44 & 3.22 & 3.50 & 3.39 & 3.09 & 0.534 & 0.001 & 0.309 & 0.06 \\
\hline MF (kg) & 0.88 & 0.80 & 0.81 & 0.88 & 0.83 & 0.914 & 0.006 & 0.061 & 0.09 \\
\hline LM (\%) & 4.02 & 3.89 & 4.21 & 3.86 & 4.16 & 0.193 & 0.020 & 0.264 & 0.03 \\
\hline TSM (\%) & 11.57 & 11.36 & 11.76 & 11.58 & 10.91 & 0.264 & 0.001 & 0.155 & 0.08 \\
\hline DSM (\%) & 8.12 & 8.15 & 8.27 & 8.16 & 7.82 & 0.347 & 0.301 & 0.129 & 0.15 \\
\hline FEMY (\%) & 1.54 & 1.53 & 1.34 & 1.51 & 1.52 & 0.156 & 0.001 & 0.376 & 0.08 \\
\hline FEECM (\%) & 1.42 & 1.35 & 1.24 & 1.35 & 1.31 & 0.361 & 0.384 & 0.825 & 0.06 \\
\hline NEL (Mcal/d) & 17.77 & 15.78 & 15.20 & 16.24 & 16.12 & 0.485 & 0.037 & 0.171 & 1.55 \\
\hline iBW (kg) & 605.67 & 605.33 & 567.67 & 567.00 & 544.33 & - & - & - & - \\
\hline fBW (kg) & 642.00 & 625.33 & 580.33 & 589.00 & 559.00 & - & - & - & - \\
\hline PUN (mg dL $\left.{ }^{-1}\right)$ & $44.53^{b}$ & $40.83 b$ & $54.28 \mathrm{a}$ & $42.85^{b}$ & $45.77 \mathrm{~b}$ & 0.024 & 0.130 & 0.872 & 1.23 \\
\hline $\operatorname{MICEF}\left(\mathrm{gCP}_{\mathrm{kgTDN}}{ }^{-1}\right)$ & 189.07 & 195.39 & 168.58 & 187.33 & 185.68 & 0.944 & 0.001 & 0.614 & 13.44 \\
\hline
\end{tabular}

MY: milk yield; ECM: energy corrected milk; MP: milk protein; MN: milk nitrogen; EN: efficiency of nitrogen usage; MF: milk fat; LM: milk lactose; TSM: total dry extract present in the milk; DSM: defatted solids in milk; FEMY: Feed efficiency based on MY; FEECM: Feed efficiency based on ECM; NEL: net energy of lactation; iBW: initial body weight; fBW: final body weight; PUN: plasma urea nitrogen concentration; MICEF: microbial efficiency.

CS: corn silage-based diet; SC: fresh sugarcane; SS: sugarcane silage-based diet without additives; SSLB: sugarcane silage-based diet with $5 \times 10^{4}$ cfu of Lactobacillus buchneri; SSLP: sugarcane silage-based diet with $5 \times 10^{4} \mathrm{cfu}$ Lactobacillus plantarum and $5 \times 10^{4}$ cfu Pediococcus pentosaceus.

${ }^{l}$ Described levels of probability ( $P$-value) for diets (D), period (P), and the influence of diets within a period (DxP). 
which highlights the need for microbial additives when ensiling sugarcane. The SSLP and CS had similar DOMI and MY, however, ECM was different. The ECM was similar among all sugarcane-based diets and was greater for CS, probably because differences observed in MY were intensified after fat percentage correction since MF did not differ among treatments. Once more, the importance of the microbial additives can be observed by the greater PUN in SS when compared with other diets, which shows that inoculants were efficient in improving $\mathrm{N}$ usage in the silo. It is likely that this higher non-protein $\mathrm{N}$ in the silo was not used in rumen once it appeared as PUN. In addition, the greater availability of rumen ammonia would explain the greater PUN values of cows fed sugarcane (Santiago et al. 2013, Andrade et al. 2016).

It is noticeable that different amounts of CP from concentrate were supplied to cows to balance dietary $\mathrm{CP}$, which is acknowledged as a possible confounding effect of the study. Sugarcane used for silages was greater in CP content than the tabulated values used at the diet formulation, which led to divergent CP contents in treatments TMRs (Table 2). Thus, the formulated diets were isonitrogenous but the diets offered to cows were not. It is important to note that it is not a mistake in formulating diets, but it is something out of control that can happen in practical situations. Furthermore, by the MICEF (185.21 $\mathrm{g} \mathrm{CP} \mathrm{kg}^{-1} \mathrm{TDN}$, on average) it can be observed a satisfactory dietary balance. The value was close to $190 \mathrm{~g} \mathrm{CP} \mathrm{kg}^{-1}$ TDN observed by Santos et al. (2011), and to $160 \mathrm{~g}$ $\mathrm{CP} \mathrm{kg}{ }^{-1} \mathrm{TDN}$ observed by Andrade et al. (2016), who also studied diets with sugarcane silage. In general, an improved balance between sugars and starch can increase the growth rates of NFC fermenting microorganisms and, when rumen $\mathrm{pH}$ is maintained within the physiological limits, microbial production is maximized (Sniffen \& Robinson, 1987).

The differences in offered $\mathrm{CP}$ were reflected in a greater CP intake in sugarcane silage-based diets compared with CS and SC. However, it is noteworthy that diet did not affect CP apparent digestibility, with an average of $87 \%$ (Table 3 ). In addition, milk production is mainly influenced by energy intake (Moe, 1981; Fernandes et al., 2001; Silva et al., 2017), not CP intake. Thus, greater CP in diet is not related to greater MY, but it could be associated to greater MP content depending on the supplied amino acid profile (NRC, 2001). Nevertheless, an improvement on MP was not observed, evidencing the slight effect of different CP contents in TMRs used in the present study. In addition, cows fed SC silages were less efficient in nitrogen usage, which can explain no positive influences on MP.

The CS presented greater NDF intake and digestibility compared with sugarcane-based diets mainly because the lower fiber quality of sugarcane, which mainly consists of rumen non-degradable compounds, causing greater retention time and, therefore, reducing voluntary intake (Magalhães et al., 2006). The NDF intake was similar between CS and SS and, within the sugarcane-based diets, SSLB and SSLP were similar and greater than SC, demonstrating a better quality of SS fiber when compared with SC. This is supported by the iNDF/NDF ratio of the forages throughout the experiment, which was 0.40 to SC and $0.35,0.37$ and 0.34 to SS, SSLB and SSLP, respectively. The sugarcane (fresh chopped) continued to mature throughout the study, while silages had their quality maintained throughout the same period. This maturing process likely decreased sugarcane fiber quality (Siqueira et al. 2010, Rezende et al. 2012), which impacted NDF intake. Nevertheless, some authors attribute reductions in consumption to the low digestibility of sugarcane NDF and mainly to the lower rate of digestion of its potentially digestible fiber, which increases digesta retention time in reticulumrumen and reduces the passage rate through the gastrointestinal tract (Magalhães et al. 2006, Oliveira et al. 2011). Since almost all the NFC in sugarcane silage is consumed by the process of fermentation in the silo, SC presented greater NFC intake compared to SS and SSLB, and greater digestibility of NFC compared with SSLB. Thus, sugarcane-based diets had similar nutrient intake because SC silages presented 
greater fiber intake, but fresh SC had greater consumption of NFC.

The SC is commonly used by dairy producers, but the need for daily chopping is often a problem. Ensiling is an alternative, but additives, such as the inoculants studied herein, are required to control the sugarcane fermentation process (Carvalho et al. 2014, Andrade et al. 2016). There was some minor alteration in NDF intake, DM, and OM digestibilities, which denotes the individualities of each diet. However, SSLB and SSLP were able to maintain DMI and MY similar to CS and SC, when greater amounts of concentrate and $\mathrm{CP}$ are supplied. The CS provided the greatest ECM, but depending on the harvest planning, labor efficiency, as well as concentrate and CP supplies, SC or sugarcane silage with inoculants can be used for dairy cows with ECM up to $23.43 \mathrm{~kg} \mathrm{~d}^{-1}$.

\section{Declarations}

\section{Funding}

The authors are grateful for the financial support of INCT/CNPq (Institutos Nacionais de Ciência e Tecnologia/Conselho Nacional de Desenvolvimento Científico e Tecnológico do Brasil), Fundação de Amparo à Pesquisa do Estado de Minas Gerais (FAPEMIG), and CAPES (Coordenação de Aperfeicoamento de Pessoal de Nível Superior).

\section{Conflict of interest}

The authors declare they have no conflicts of interest with regard to the work presented in this report.

\section{Author contributions}

Lucas L Cardoso: data curation, investigation, formal analysis, writing original draft. Karina $G$ Ribeiro: conceptualization, methodology, project administration, resources, supervision. Odilon G Pereira: conceptualization, methodology, project administration, resources, supervision. Kirsten Weiss: methodology, supervision, review. Geraldo F V Bayão: data curation, investigation, formal analysis, writing original draft. Camila S Cunha: investigation, writing original draft, review and editing. Marcos I Marcondes: conceptualization, methodology, project administration, resources, supervision, writing original draft, review and editing.

\section{References}

Andrade FL, Rodrigues JPP, Detmann E, Valadares Filho SC, Castro MMD, Trece AS, Silva TE, Fischer V, Weiss K, Marcondes MI. Nutritional and productive performance of dairy cows fed corn silage or sugarcane silage with or without additives. Trop Animal Health Pro 2016; 48(4): 747-753. DOI: https://doi.org/10.1007/s11250-016-1020-y

Association of Official Analysis Chemists International (AOAC). Official Methods of Analysis. $15^{\text {ed }}$. AOAC, Arlington, VA, USA, 1990.

American Oil Chemists' Society (AOCS). Rapid Determination of Oil/Fat Utilizing High Temperature Solvent Extraction. AOCS Standard Procedure Am 5-04. Urbana, IL, USA, 2004.

Ávila CLS, Bravo Martins CEC, Schwan RF. Identification and characterization of yeasts in sugarcane silages. J Appl Microbiol 2010; 109(5): 1677-1686. DOI: https://doi.org/10.1111/j.1365-2672.2010.04796.x

Ávila CLS, Pinto JC, Oliveira DP, Schwan RF. Aerobic stability of sugar cane silages with a novel strain of Lactobacillus sp. isolated from sugar cane. R Bras Zootec 2012; 41(2): 249-255. DOI: https://doi.org/10.1590/S1516-35982012000200003

Broderick GA, Clayton MK, 1997. A statistical evaluation of animal and nutritional factors influencing concentrations of milk urea nitrogen. J Dairy Sci 80(11): 2964-2971. DOI: https://www.ncbi.nlm.nih.gov/pubmed/9406089

Carvalho BF, Ávila CLS, Pinto JC, Neri J, Schwan RF. Microbiological and chemical profile of sugar cane silage fermentation inoculated with wild strains of lactic acid bacteria. Anim Feed Sci Technol 2014; 195: 1-13. DOI: https://doi.org/10.1016/j.anifeedsci.2014.04.003 
Chen XB, Gomes MJ. Estimation of microbial protein supply to sheep and cattle based on urinary excretion of purine derivatives - an overview of the technical details. Rowett Research Institute, Bucksburnd Aberdeen, 1992.

Costa LT, Silva FF, Veloso CM, Pires AJV, Oliveira JS, Azevedo ST, Silva VL. Performance, digestibility, production and composition of milk from crossbred cows receiving different levels of concentrateinthediets basedonsugarcane. RevBras Saúde Prod Anim 2009; 10(4): 1019-1031. DOI: https://www.cabdirect.org/cabdirect/ abstract/20103290821

Detmann E, Souza MA, Valadares Filho SC, QueirózAC, Berchielli TT, Saliba EOS, Cabral LS, Pina DS, Ladeira MM, Azevedo JAG. Métodos para Análise de Alimentos. Suprema Gráfica, Visconde do Rio Branco, MG, Brazil, 2012.

Detmann E, Valadares Filho SC. On the estimation of non-fibrous carbohydrates in feeds and diets. Arq Bras Med Vet Zoo 2010; 62(4): 980-984. DOI: https://doi.org/10.1590/S0102$\underline{09352010000400030}$

Fernandes AM, Queiroz AC, Lana RP, Pereira JC, Cabral LS, Vittori A, Pereira ES. Estimativas da produção de leite por vacas holandesas mestiças, segundo o sistema CNCPS, em dietas contendo cana-de-açúcar com diferentes valores nutritivos. Rev Bras Zootec 2001; 30(4): 1350-1357. DOI:https://doi.org/10.1590/S1516-35982001000500031

Gaines WL. 1928. The energy basis of measuring milk yield in dairy cows. Illinois agricultural experiment station bulletin 308. Urbana: University of Illinois.

George SK, Dipu MT, Mehra UR, Singh P, Verma AK, Ramgaokar JS. Improved HPLC method for the simultaneous determination of allantoin, uric acid and creatinine in cattle urine. J Chromatogr B 2006; 832(1):134-137. DOI: https://doi.org/10.1016/j.jchromb.2005.10.051

Licitra G, Hernandez TM, Van Soest PJ. Standardization of procedures for nitrogen fractionation of ruminant feeds. Anim
Feed Sci Tech 1996; 57(4): 347-358. DOI: https://doi.org/10.1016/0377-8401(95)00837-3

Magalhães ALR, Campos JMS, Cabral LS, Mello R, Freitas JA, Torres RA, Valadares Filho SC, Assis AJ. Effects of replacing corn silage with sugarcane on production and ruminal metabolism of lactating dairy cows. R Bras Zootec 2006; 35(2): 591-599. DOI: https://doi.org/10.1590/S1516-35982006000200036

Moe PW. Energy Metabolism of Dairy Cattle. J Dairy Sci. 1981; 64(6): 1120-1139. DOI: https://doi.org/10.3168/jds.S0022-0302(81)82692-6

Morris TR. Experimental Design and Analysis in Animal Sciences. CABI Publishing, Wallingford, OFE, UK, 1999.

Nutrients Requirements Council (NRC). Nutrient Requirements of Dairy Cattle. 7ed. National Academy Press, Washington, DC, USA, 2001.

Oliveira AS, Detmann E, Campos JMS, Pina DS, Souza SM, Costa MG. Meta-analysis of the impact of neutral detergent fiber on intake, digestibility and performance of lactating dairy cows. Rev Bras Zootec 2011; 40(7): 1587-1595. DOI: https://doi.org/10.1590/S1516-35982011000700026

Pedroso AF, Rodrigues AA, Barioni Júnior W, Souza GB. Fermentation parameters, quality and losses in sugarcane silages treated with chemical additives and a bacterial inoculant. Rev Bras Zootec 2011; 40(11): 2318-2322. DOI: https://doi.org/10.1590/S1516-35982011001100006

Queiroz OCM, Nussio LG, Schmidt P, Ribeiro JL, Santos MC, Zopollatto M. Sugar cane silage as compared to traditional supplemental sources of forage in the performance of high production cows. Rev Bras Zootec 2008(2); 37: 358-365. DOI: https://doi.org/10.1590/S1516-35982008000200024

RangelAHN, Campos JMS, OliveiraAS, Valadares Filho SC, Assis AJ, Souza SM. Performance and nutritional parameters of growing heifers fed corn silage or sugar cane with concentrate. Rev Bras Zootec 2010; 39(11): 2518-2526. DOI: https://doi.org/10.1590/S1516-35982010001100027 
Rezende AV, Senedese SS, Rabelo CHS, Nogueira DA, Vieira PF, Rabelo FHS. Chemical composition and "in vitro" dry mass digestibility of sugarcane with urea in different storage times. Rev Bras Saúde Prod Anim 2012; 13(1): 25-34. DOI: https://doi.org/10.1590/S1519-99402012000100003

Santiago AMF, Campos JMS, Oliveira AS, Valadares Filho SC, Santos SA, Souza SM, Santiago IF. Urea in sugarcane-based diets for dairy cows. Rev Bras Zootec 2013; 42(6): 456-462. DOI: https://doi.org/10.1590/S1516-35982013000600010

Santos SA, Valadares Filho SC, Detmann E, Valadares RFD, Ruas JRM, Amaral PM. Different forage sources for F1 Holstein x Gir dairy cows. Livest Sci 2011; 142(1): 48-58. DOI: https://doi.org/10.1016/j.livsci.2011.06.017

Santos WP, Ávila CLS, Neves MP, Schwan RF, Lopes NM, Pinto JC. Effect of the inoculation of sugarcane silage with Lactobacillus hilgardii and Lactobacillus buchneri on feeding behavior and milk yield of dairy cows. J Anim Sci 2017; 95(10):4613-4622. DOI: https://doi.org/10.2527/jas2017.1526

SAS $^{\circledR}$, Statistical Analisys System. SAS/STAT User's Guide. Version 9.2. Cary, NC: SAS Institute Inc; 2008.

Schmidt P, Nussio LG, Queiroz COM, Santos MC, Zopollatto M, Toledo Filho SG, Daniel JLP.

Effects of Lactobacillus buchneri on the nutritive value of sugarcane silage for finishing beef bulls. Rev Bras Zootec 2014; 43(1): 8-13. DOI: https://doi.org/10.1590/S1516-35982014000100002
Silva AL, Castro MMD, Rotta PP, Machado WS, Abreu MB, Villanova DFQ, Marcondes MI. Suplementação energética vs proteica para bovinos de leite sob pastejo. Proceedings of the VI Simpósio Internacional de Bovinocultura de Leite SIMLEITE; 2017 Nov 2-4; Viçosa, Brazil. Visconde do Rio Branco: Suprema. Access date: november $10^{\text {th }} 2020$. https://www.simleite.com/arquivosAnais/arquivo209

Siqueira GR, Reis RA, Schocken-Iturrino RP, Pires AJV, Bernardes TF, Roth MTP. Burning and chemical and bacterial additives in sugar cane silage. RevBrasZootec 2010;39(1): 103-112.DOI: https://doi.org/10.1590/S1516-35982010000100014

Sniffen CJ, Robinson PH. Microbial growth and flow as influenced by dietary manipulations. J Dairy Sci 1987; 70(2):425-441. DOI: https://doi.org/10.3168/jds.S0022-0302(87)80027-9

Talke H, Schubert GE. Enzymatic urea determination in the blood and serum in the warburg optical test. Klin Wochenschr 1965; 43: 174-175. DOI: https://doi.org/10.1007/BF01484513

Zielińska K, Fabiszewska A, Stefańska I. Different aspects of Lactobacillus inoculants on the improvement of quality and safety of alfalfa silage. Chil J Agr Res 2015; 75(3): 298-306. DOI: http://dx.doi.org/10.4067/S0718-58392015000400005

WeissWP,ConradHR, St.PierreNR.Atheoreticallybased model for predicting total digestible nutrient values of forages and concentrates. Anim Feed Sci Tech 1992;39(1): 95-110. DOI: https://doi.org/10.1016/0377-8401(92)90034-4 